\title{
Congenital Clavicular Pseudarthrosis - A Rare Diagnosis
}

\author{
Marta Isabel Pinheiro ${ }^{1 *}$, Cristina Ferreras ${ }^{1}$, Jorge Coutinho ${ }^{2}$, Maria Gorett Silva ${ }^{1}$ and Hercília Guimarães ${ }^{1,3}$ \\ ${ }^{1}$ Department of Neonatology, Regular Nursery, Centro Hospitalar e Universitário de São João, Portugal \\ ${ }^{2}$ Paediatric Orthopaedic Unit, Department of Orthopaedics and Traumatology, Centro Hospitalar e Universitário de São João, Portugal \\ ${ }^{3}$ Faculty of Medicine, University of Porto, Portugal
}

Submission: November 26, 2019; Published: December 11, 2019

*Corresponding author: Marta Isabel Pinheiro1, Department of Neonatology, Regular Nursery, Centro Hospitalar e Universitário de São João, Portugal

Keywords: Congenital clavicular pseudarthrosis; Clavicle congenital anomaly; Pseudarthrosis; Neonatology

\section{Introduction}

Female newborn with an uneventful pre-natal history. Vaginal delivery at 40 weeks and 3370gr (10-50th percentile) of birth weight. On the first day of life, the pediatrician describes a crackling in the middle third of the right clavicle with symmetrical Moro reflex, no palpable swelling or painful region and normal mobility of the upper limbs. Radiological study confirmed the diagnosis of congenital pseudarthrosis of the clavicle, showed an interruption in the medial region of the clavicle with rounded edges and no evidence of bone callus formation (Figure 1). The patient follow-up is in Children`s Orthopaedics outpatient, remains asymptomatic and has no other clinical complications. Congenital clavicular pseudarthrosis is a rare benign anomaly [1], first reported in 1910 [2]. This condition resulting in a failure of coalescence of the two primary ossification centers, during embryogenesis, which produces two portions of the clavicle connected by a fibrous bridge. The exact etiology is unknown. Ninety percent occur on the right side and it's more prevalent in girls [3]. Bilateral occurrence may be associated with genetic syndromes. Generally, simple radiography is sufficient to confirm the diagnosis [4]. Differential diagnosis, especially in neonates, mainly includes the clavicle fracture due to birth trauma [1]. However, when the clinical findings are contradictory, this condition should be considered, with radiology being an important auxiliary. In most situations, an expectant attitude is adopted. Surgical treatment is recommended when there are functional limitations, progressive pain, onset thoracic outlet syndrome or unacceptable cosmetic deformity [3].

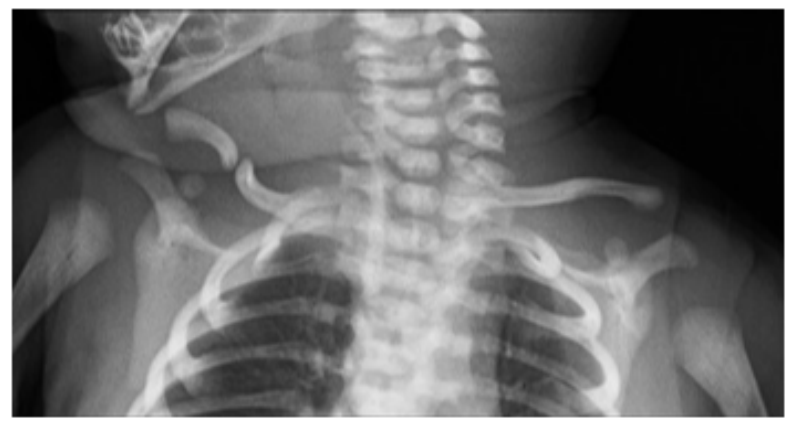

Figure 1: Newborn clavicular pseudarthrosis. 
Conflict of interest: The authors confirm that there are no known conflicts of interest associated with this publication.

\section{References}

1. Ducic S, Bojovic N, Raicevic M, Radlovic V, Djuricic G, et al. (2017) Late presentation of congenital pseudarthrosis of the clavicle. International Journal of Orthopaedics 3(4): 536-539.

2. Fitzwilliams DL (1910) Hereditary cranio-cleido-dysostosis: with a review of all the published cases of this disease: theories of the development of the clavicle suggested by this condition. The Lancet 176(4551): 1466-1475.

3. Di Gennaro GL, Cravino M, Martinelli A, Berardi E, Rao A, et al. (2017) Congenital pseudarthrosis of the clavicle: a report on 27 cases. J Shoulder Elbow Surg 26(3): 65-70.

4. Currarino G, Herring JA (2009) Congenital pseudarthrosis of the clavicle. Pediatr Radiol 39(12): 1343-1349.

\section{Your next submission with Juniper Publishers will reach you the below assets}

- Quality Editorial service

- Swift Peer Review

- Reprints availability

- E-prints Service

- Manuscript Podcast for convenient understanding

- Global attainment for your research

- Manuscript accessibility in different formats

( Pdf, E-pub, Full Text, Audio)

- Unceasing customer service

Track the below URL for one-step submission

https://juniperpublishers.com/online-submission.php 